\title{
Effects of diesel oil spill on macrobenthic assemblages at the intertidal zone: A mesocosm experiment in situ
}

\author{
Zhengquan Zhou ${ }^{\text {a,b }}$, Xiaojing Li ${ }^{\text {a,b }}$, Linlin Chen ${ }^{\text {a }}$, Baoquan Li $^{\text {a, }}$, Chuanyuan Wang ${ }^{\text {a, }}{ }^{, * *}$, \\ Jie Guo ${ }^{a}, \mathrm{Pu} \mathrm{Shi}^{\mathrm{b}}$, Lufei Yang ${ }^{\mathrm{c}}, \mathrm{Bo} \mathrm{Liu}^{\mathrm{c}}$, Bo Song ${ }^{\mathrm{c}}$ \\ ${ }^{\text {a }}$ Yantai Institute of Coastal Zone Research, Chinese Academy of Science, Yantai, 264003, China \\ ${ }^{\mathrm{b}}$ University of Chinese Academy of Science, Beijing, 10049, China \\ ${ }^{\mathrm{c}}$ University of Yantai, 264003, China
}

\section{A R T I C L E I N F O}

\section{Keywords:}

Oil spill

In situ experiment

Macrobenthos

Community variation

M-BACI

\begin{abstract}
A B S T R A C T
The oil spill accidents may drastically impact the environment and ecosystem at intertidal zones. The spilled oil will penetrate the sediments and accumulate to cause lethal or sublethal effects on the benthic invertebrates. An M-BACI experiment was manipulated in situ to assess the ecological responses of benthic macrofauna to different degrees of diesel oil spill. Both biotic and abiotic parameters were studied for 126 days, subjected to both "pulse" and "press" oil contaminations. The content of aliphatic hydrocarbons (displayed as ratios of $n$-C17/Pr and $n$ $\mathrm{C} 18 / \mathrm{Ph}$ ) slightly dropped then continuously existed in the sediment during the experiment time. The macrofaunal assemblage structures were dramatically altered in species number, abundance and biomass. In general, it takes longer time for the macrofauna assemblages to recover under high concentration oil spill than that under low concentration. Our results highlight the diversified strategies for survival and recolonization among dominant species, which distinguish themselves between: $i$ ) tolerant species, ii) opportunistic species, and iii) equilibrium species.
\end{abstract}

\section{Introduction}

Oil spill is among the most deleterious anthropogenic influences on coastal environments worldwide (Ahn and Choi, 1998; Hawkins et al., 2017; Lumibao et al., 2018; Uno et al., 2017). The oil spill pollutants are widely detected with an increasing rate both in water and on land (Ko and Day, 2005; Pezeshki et al., 2000). The spilled oil will spread to the intertidal zone following the tide and wave, then accumulate into the sediment (from $15 \mathrm{~cm}$ to $100 \mathrm{~cm}$ in depth) above the high-tide line. The persistent periods of the spilled oil layers may vary from several months to decades under different degrees of sheltering (Bejarano et al., 2006; Dauvin, 2000; Peterson et al., 2003; Yamamoto et al., 2003).

Intertidal flats provide perfect living habitats with high level of organics and nutrients for various species (Cusson and Bourget, 2005; Heck et al., 2006; Van Der Meer et al., 2001). These areas are widely concerned for perturbations related with anthropogenic activities (Ahn and Choi, 1998; De Jonge, 2000; Robertson et al., 2015; Xiong et al., 2015; Zhang et al., 2013). Macrobenthos are key components of invertebrate communities on intertidal flats and they take significant positions in the local food chains (Aller, 1982). Because of their sedentary living behavior and sensibility to the environmental pollutants, macrobenthos are widely used as a sort of biota indicators to evaluate the health conditions of benthic environments (Anderson and Marti J, 2008; Borja and Tunberg, 2011).

The petroleum hydrocarbons released during the oil spill process are the main pollutants for marine organisms (Díez et al., 2007; Joydas et al., 2012). They will cause lethal or sublethal effects on sand beach invertebrates, attenuating or interfering the physiological process such as feces or pseudofeces production, net carbon flux, feeding activity and filtration rate (Bejarano et al., 2006; Ekeroth et al., 2016). The amount of certain pollutant-sensitive species tends to decrease under oil pollution, while the pollutant-tolerant species will survive and recolonize into some spare niche, presenting a different distribution pattern. Some pollutant-tolerant species even become as the new dominant species after the contamination impact, benefitting from the migration or exclusion of previous dominant species (Amaro et al., 2018; Goldberg,

\footnotetext{
* Corresponding author.

** Corresponding author.

E-mail address: bqli@yic.ac.cn (B. Li).
} 
1975; Grassle and Frederick Grassle, 1976; Roy et al., 2018).

Our study area is a marine ranching intertidal zone managed and protected by the Blue Ocean Science and Technology Co., Ltd., which is located at the coast of the Laizhou Bay, Bohai Sea. The Bohai Sea takes an essential role in both ecological and aquaculture functions in China. Moreover, it maintains the highest number of oil platforms among China's four offshore sea areas. A rising number of oil spill accidents are reported within this area over the years (Hu et al., 2000). By harvesting the economic species, such as mollusks Ruditapes philippinarum, Bullacta caurina, Cyclina sinensis, and Meretrix, the company shares a stable yearly income of about 288 thousand USD (according to the local manager). The company also runs offshore farming of sea cucumber Apostichopus japonicus. Fishing boats powered by diesel oil shuttling back and forth along the intertidal aquaculture zone every day. Then the diesel oil often leaks into the routine sea waters, either intentionally or unintentionally dispersing to the adjacent intertidal zone. Thus, it's essential to study the effects of diesel oil leakage on the living conditions of the economic species.

Our aims in this study were to: $i$ ) evaluate the ecological effects of oil spill and how it alters benthic community structure in-situ at intertidal flats, expressed by major changes of dominant species and community compositions before and after the oil impact; ii) observe the recovery time of macrobenthic assemblages considering species number, abundance and biomass; iii) to fulfill the gap between diesel oil leakage and intertidal zone ecosystem. We anticipated that, with the manipulative treatment of simulated oil spill, the following consequences should be captured: $i$ ) the macrobenthic communities will be disturbed by the spilled diesel oil, and the species composition will be changed by the increasing of pollutant-tolerant species and decreasing of pollutantsensitive species; ii) the benthic fauna will recolonize quickly at low concentration of oil spill accident, yet hardly recover to the pre-spill levels in a short time from severe oil spill event.

\section{Material and methods}

\subsection{Experiment design}

The Multivariate Before and After/Control and Impact (M-BACI) routine is a sampling strategy well suitable for analyzing the planned experimental impacts (Underwood, 2000). In an M-BACI approach, sampling activities are replicated both spatially and temporally, to make credible interpretations for the treatment effects before and after the impact. An M-BACI experiment was applied at Laizhou city of Shandong
Province, China (Fig. 1). The experimental temporal scale was from Apr. 4 to Aug. 17 in 2015, with a simulated oil spill impact on June 19 (Table 1). Twelve pre-planned sampling times were symmetrically arranged during the experimental 126 days temporal scale, with 6 times before (Day-63, Day-35, Day-18, Day-3, Day-2, Day-1) and 6 times after $\left(\mathrm{Day}_{1}, \mathrm{Day}_{2}, \mathrm{Day}_{3}, \mathrm{Day}_{18}, \mathrm{Day}_{35}, \mathrm{Day}_{63}\right.$ ) the simulated oil spill, respectively (Fig. 2).

One control plot and three different degrees of impact plots $(500 \mathrm{ml}$, $2000 \mathrm{ml}$ and $4000 \mathrm{ml}$ ) were set at an unvegetated tidal flat along the Laizhou Bay: control plot (N 37 $08^{\prime} 14.747^{\prime \prime}$, E $199^{\circ} 44^{\prime} 44.700^{\prime \prime}$ ), $500 \mathrm{ml}$ oil spill impact plot (N 37 $08^{\prime} 14.870^{\prime \prime}$, E $\left.119^{\circ} 44^{\prime} 43.486^{\prime \prime}\right), 2000 \mathrm{ml}$ oil spill impact plot (N $37^{\circ} 08^{\prime} 14.903^{\prime \prime}$, E $\left.119^{\circ} 44^{\prime} 42.300^{\prime \prime}\right)$ and $4000 \mathrm{ml}$ impact plot (N 37 $08^{\prime} 14.966^{\prime \prime}$, E 119 $44^{\prime} 41.091^{\prime \prime}$ ). Each of the control and impact plots were set $30 \mathrm{~m}$ apart from each other parallel to the coastline, to minimize the mutual interference and ensure the same tidal effects. The amount and gradients of the diesel oil used in this experiment were defined based on previous studies and our own pilot tests. Egres et al. (2012) used $2500 \mathrm{ml}$ marine diesel as single treatment in their study (relatively same sediment type and impact size as ours). We also carried out a pilot experiment at the target spot using the same mesocosms with NO.0 diesel concentrations of $250 \mathrm{ml}, 500 \mathrm{ml}, 1000 \mathrm{ml}$, $2000 \mathrm{ml}, 3000 \mathrm{ml}, 4000 \mathrm{ml}$ and $5000 \mathrm{ml}$. We collected macrobenthos samples in each of these treatments after deploying diesel oil for 7 days. By checking the mortality rate, locomotion and body deficient conditions and of the macrofauna specimens, we choose $500 \mathrm{ml}, 2000 \mathrm{ml}$ and $4000 \mathrm{ml}$ as our final treatment concentrations.

The geographical location (e.g. regular inundation and dry time

Table 1

The sampling schedule in accordance with the M-BACI sampling design.

\begin{tabular}{|c|c|c|c|c|c|}
\hline Before oil spill & Date & Oil spill & Date & After oil spill & Date \\
\hline Day $_{-63}$ & $\begin{array}{l}15-4- \\
2015\end{array}$ & Day $_{0}$ & $\begin{array}{l}17-6- \\
2015\end{array}$ & Day $_{1}$ & $\begin{array}{l}18-6- \\
2015\end{array}$ \\
\hline Day. $_{35}$ & $\begin{array}{l}13-5- \\
2015\end{array}$ & & & $\mathrm{Day}_{2}$ & $\begin{array}{l}19-6- \\
2015\end{array}$ \\
\hline Day $_{-18}$ & $\begin{array}{l}30-5- \\
2015\end{array}$ & & & $\mathrm{Day}_{3}$ & $\begin{array}{l}20-6- \\
2015\end{array}$ \\
\hline Day $_{-3}$ & $\begin{array}{l}14-6- \\
2015\end{array}$ & & & Day $_{18}$ & $5-7-2015$ \\
\hline Day-2 $_{-2}$ & $\begin{array}{l}15-6- \\
2015\end{array}$ & & & $\mathrm{Day}_{35}$ & $\begin{array}{l}22-7- \\
2015\end{array}$ \\
\hline Day $_{-1}$ & $\begin{array}{l}16-5- \\
2015\end{array}$ & & & Day $_{63}$ & $\begin{array}{l}17-8- \\
2015\end{array}$ \\
\hline
\end{tabular}

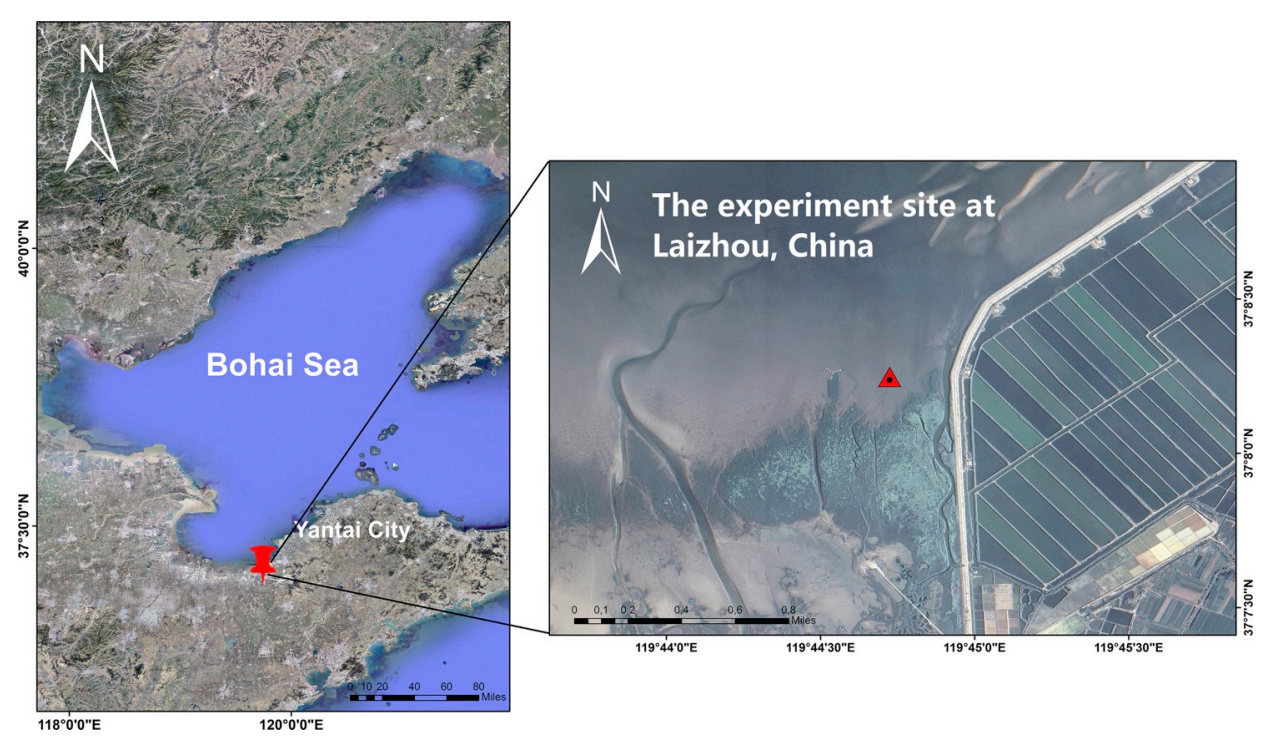

Fig. 1. The satellite image of the study location at Laizhou, Shandong Province, China. 


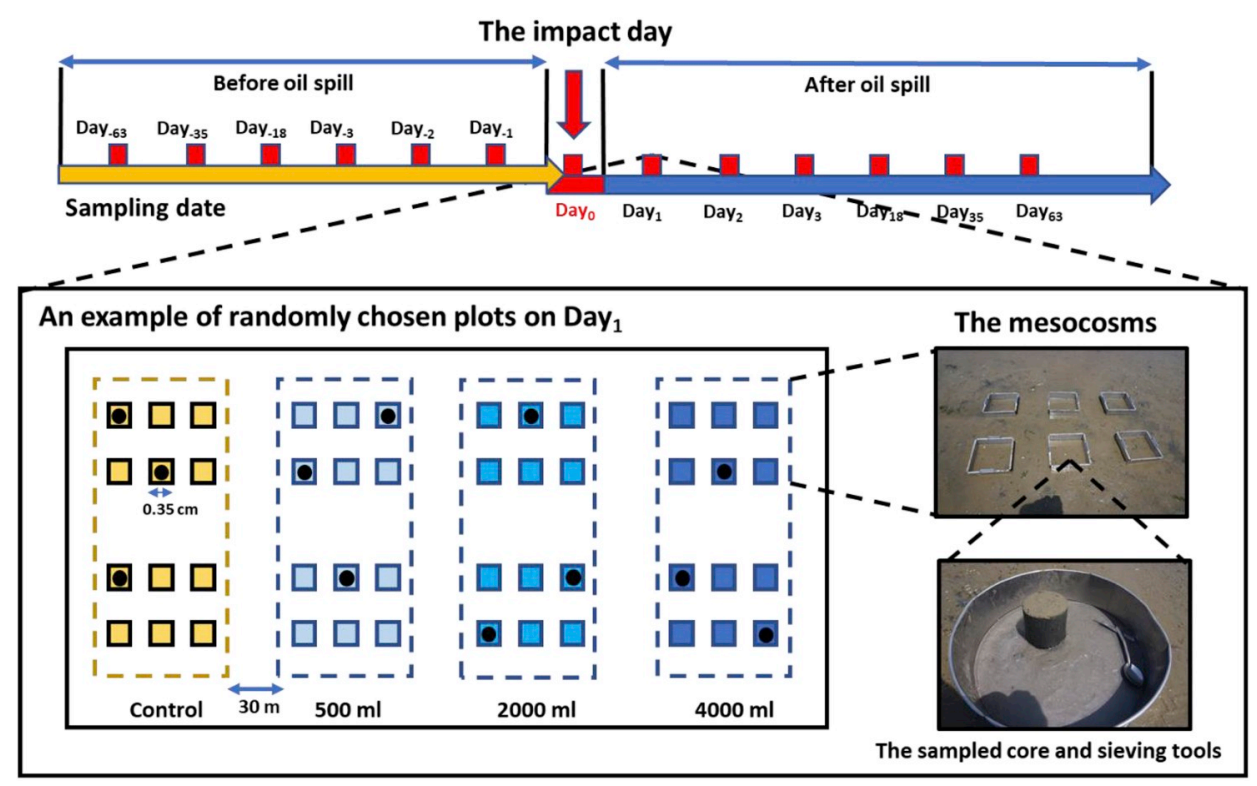

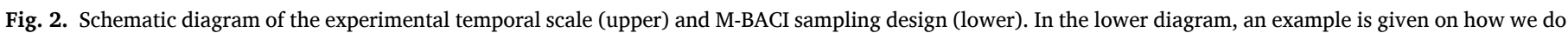

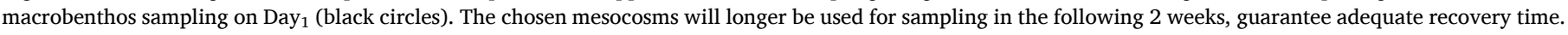

varying with the local tides) and the wind turbines around on the dike allow us to judge the environment as mid-tide zone with strong wind exposure, though the hydrodynamics were not measured during the experiment. The experimental area was protected well by the staffs from Blue Ocean Science and Technology Co., Ltd during the sampling time scale, to minimize other anthropogenic interferences. The diesel oil used in this experiment was provided by them.

We use diesel oil as our experimental treatment, although oil spill accidents are witnessed for both crude oil and diesel oil. The main reasons are as follows, $i$ ) the diesel fuel is commonly used for ships running in Chinese seawaters and other parts of the world, yet the effects of the leakage spreading to tidal flats are often ignored; ii) the diesel oil contains smaller proportion of persistent pollutants as compared to crude oil, which would cause less deleterious effects on local environment conditions. We used NO.0 diesel oil to simulate different concentrations of oil spill. According to regulation GWKB 1.2-2011 adopted by the Ministry of Ecology and Environment of P.R. China, the mass fraction of polyaromatic hydrocarbons (PAHs) in NO.0 diesel should be no more than $11 \%$, and the sulfur content no more than $50 \mathrm{mg} / \mathrm{kg}$. The NO.0 diesel fuel is widely used on diesel engine vehicles and fishing boats in China.

In order to further reduce the ecological impact of diesel oil, we adopt the method of mesocosm experiment in situ to simulate oil spill within a controlled scale (Fig. 2). In each of the control and impact plots, 12 mesocosms were set and arranged in 4 rows, using $0.35 \times 0.35 \times 0.2 \mathrm{~m}^{3}$ stainless steel frames (no cover and bottom) inserted into the sediment $(0.15 \mathrm{~m}$ buried in the sediment, $0.05 \mathrm{~m}$ appear above the ground).

To mimic the coverage effect of an oil spill, we firstly dumped $200 \mathrm{ml}$ diesel oil in each mesocosm, then mixed the rest diesel oil with $0.35 \times 0.35 \times 0.05 \mathrm{~m}^{3}$ defaunated sand and put the oil-sand mixture above the sediment (i.e. for the $2000 \mathrm{ml}$ impact plot, directly dumping $200 \mathrm{ml}$ in each mesocosm and cover on top oil-sand mixture using $1800 \mathrm{ml}$ diesel oil). In this way, all mesocosms were directly soaked with $200 \mathrm{ml}$ and covered with $0.05 \mathrm{~m}$ height oil-sand mixture on top. The simulated oil spill impact was done during the low tide time, when most of the intertidal zone was emerged.

\subsection{Macrobenthos sampling strategies}

Three mesocosm were randomly chosen from each of the 4 plots (control and impact) on every 12 sampling days (Fig. 2). Once a mesocosm was used for sampling, it would no longer be used in the next 14 days to bring into as less disturbance and enough time for the fauna recovery. Macrobenthic samples were collected with a cylindrical sediment corer of $10 \mathrm{~cm}$ in diameter and $20 \mathrm{~cm}$ in height, and then sieved in situ with a $0.5 \mathrm{~mm}$ mesh sieves. The alive macrobenthos samples were preserved in $80 \%$ ethanol and identified to the lowest possible taxonomic level (mostly species) in laboratory, then counted and weighted using a $0.001 \mathrm{~g}$ precision electric balance.

\subsection{Environmental variable sampling and analysis}

In each treatment, sediment samples were collected for particle size analysis on the starting and ending day of this experiment (Day-63 and Day63) as well as the 2nd day before and after the oil spill experiment $\left(\right.$ Day $_{-2}$ and Day $_{2}$ ). Moreover, for better understanding the dynamic process (accumulative or dispersal) of the diesel oil in the sediment, extra sediment samples were collected for aliphatic hydrocarbons analysis. These samples were only taken on 2nd, 35th and 63rd days after the simulated oil spill impact $\left(\right.$ Day $_{2}$, Day $_{35}$ and Day 63 ) in each of 3 impact plots, to minimize the time and material costs. All sediment samples were preserved in aluminum foils in the field and oven dried under $40^{\circ} \mathrm{C}$ in lab, then stored in glass vials for further hydrocarbon analysis.

The sample extraction and extract purification/fractionation of $n$ alkanes processed in this study were described in detail by Wang et al. (2011). The concentration of every individual $n$-alkane was calculated with reference of the standard calibration curve of relative standard compound. The minimum limit of method detection for each aliphatic or aromatic compound is $10 \mathrm{ppb}$. In this study, peak areas from the $m / z=85$ chromatograms were used to calculate $n$-alkane biomarker ratios in this research.

\subsection{Data processing}

The M-BACI model in this experiment was established with the following factors: treatments (4 levels, random and orthogonal), periods ( 2 levels, fixed and orthogonal), and sampling times (6 levels, fixed and nested in each periods). A permutational multivariate analysis of variance (PERMANOVA) was performed to test the significance of overall difference between treatments, using PRIMER 7.0 software package 
(PRIMER-E Ltd., Plymouth Marine Laboratory, Plymouth, U.K.).

Average abundance in control and impact plots were transformed by $\log (\mathrm{x}+1)$, and then Bray-Curtis similarity matrices S17 were calculated using these transformed data. A non-metric multidimensional scaling ( $n$ MDS) was applied to visualize the community structure variations in different treatment plots before and after the simulated oil spill. The significance of difference in total abundance and species number between treatments were tested using aov ( ) function built in software $R$ 3.6.0.

Moreover, dominant species were defined according to the $Y$ dominant index (Chen et al., 1995). The dominant index $Y_{i}$ for a certain species $i$ is calculated by formula:

$Y_{i}=\left(n_{i} / N\right) \times f_{i}$

where $N$ is the total abundance of all the stations; $n_{i}$ is the total abundance of the species $i$ among all sampling days; $f_{i}$ is the occurrence frequency of the species $i$ on each sampling day; species $i$ can be defined as the dominant species when $Y_{i}>0.02$. The average abundance of dominant species was calculated to indicate the variation tendency during experiment temporal scale.

\section{Results}

\subsection{Environmental variables}

The sediment was mostly characterized by coarse sand in the experimental area (Table 2). The grain size did not show any significant difference before and after the simulated oil spill, with more than $90 \%$ of the contents were fine sand $(>63.00 \mu \mathrm{m})$. This indicated that the sediment had not undergone drastic changes induced by the oil spill treatment. At the same time, tides (basically coincided with data of the Laizhou port from China Shipping Service website) and temperatures were within the normal local range (from 10 to $33^{\circ} \mathrm{C}$ ), and no extreme weather disturbances were encountered during the experimental temporal scale.

The degradation rate of aliphatic hydrocarbons (AHs) were displayed in Fig. 3, in which the degradation rate were expressed with the ratios of $n$ - $\mathrm{C}_{17}$ to pristane (Pr) and $n-\mathrm{C}_{18}$ to phytane (Ph). Normally, the $n$-alkanes would be degraded prior to significant alteration of other compound classes, resulting in lower $n-\mathrm{C}_{17} / \mathrm{Pr}$ and $n-\mathrm{C}_{18} / \mathrm{Ph}$ ratios for slightly or moderately biodegraded oils than their non-biodegraded counterparts.

The $n-\mathrm{C} 17 / \mathrm{Pr}$ ratio in control plots are relatively constant, with average values range from $4.87 \pm 0.05$ ( Day $_{2}$ ) to $4.73 \pm 0.54$ (Day63). The $n$-C17/Pr ratio showed divergence variation trends in each of the impact groups. In the $500 \mathrm{ml}$ impact group, the ratio decreased from $2.26 \pm 0.08$ to $1.90 \pm 0.18$, indicating the natural process of degradation (biogenic/terrestrial). In the $2000 \mathrm{ml}$ impact group, the ratio increased from $2.21 \pm 0.03$ to $2.95 \pm 0.19$. This ascending trend of $n$-C17 content indicated the accumulation process of the biodegradation products from dead macrobenthos bodies. The ratio in $4000 \mathrm{ml}$ impact group remain basically the same on the first and last day after the diesel oil treatment, indicating a sustained impact due to a high concentration.

The $n$-C18/Pr ratio in control plots are stable with average values range from $4.53 \pm 0.15\left(\right.$ Day $\left._{2}\right)$ to $4.28 \pm 0.26$ (Day 63 ). The $n-C 18 / P h$ ratio experienced slight changes in either one of three impact groups, yet the decreasing rate still follow the treatment gradients. More reduction of $n$-C18 was witnessed in $500 \mathrm{ml}$ impact group (from $2.02 \pm 0.27$ to $1.71 \pm 0.03$ ) than that in 4000 group (from $2.13 \pm 0.10$ to $2.03 \pm 0.40$ ). This indicated different retentivity of the diesel oil in sediment caused by concentrations.

\subsection{Variation of species composition, biomass and abundance}

In total, 35 macrobenthos species were obtained at the sampling intertidal area, among which Mollusca was the most abundant taxon with 16 species (45.71\%), followed by Polychaeta with 12 species (34.29\%). Crustaceans comprised $17.14 \%$ of the total fauna with 6 species, and 1 Nemertea took the least composition. The mean values of abundance, biomass and species number are shown by treatment groups in Figs. 4-6. In order to better capture the variation trend induced by the simulated oil spill, only subsets on Day-1, Day ${ }_{1}$ and Day ${ }_{63}$ are displayed.

The mean abundance showed little difference before and after the oil spill (on Day-1 and Day ${ }_{1}$ ) in the control group, yet experienced various degrees of decline in all impact groups (Fig. 4). The abundance had not recovered in $500 \mathrm{ml}$ and $2000 \mathrm{ml}$ groups but exceeded the pre-spill levels in $4000 \mathrm{ml}$ group.

The mean biomass increased in $500 \mathrm{ml}$ and $2000 \mathrm{ml}$ impact groups, while slightly decreased in $4000 \mathrm{ml}$ group one day after the oil spill (Fig. 5). At the end of the experiment, the biomass exceeded the pre-spill levels in both control and impact treatments. More obvious increasing was recorded in $4000 \mathrm{ml}$ group than any other impact groups.

The mean species number decreased in all impact groups after the simulated oil spill, with mean values above 5 species on Day-1 dropping to below 5 on Day 63 (Fig. 6). In contrast to the stable condition in the control group, the average species number in any of the impact groups did not return to pre-spill levels after 63 days of the oil spill disturbance.

\subsection{Dominant species}

Five species were identified as the dominant species according to their dominant values $Y$ during our experiment $(Y>0.02)$, including 2 mulluscs Batillaria cumingii ( $Y=0.34$ ) and Iridona iridescens $(Y=0.051)$; 2 polychates Armandia intermedia $(Y=0.16)$ and Hediste japonica $(Y=0.028)$; and 1 crustacean Diastylis tricincta $(Y=0.058)$.

The 5 dominant species showed entirely different response to the process of simulated oil impact. B. cumingii was witnessed for an increasing of abundance in all impact groups after simulated oil spill, comparing to control group within the sampling time scale (Fig. 7a). $A$. intermedia and $D$. tricincta experienced a dramatic raise two days after the oil spill, yet gradually disappeared in the subsequent sampling dates (Fig. $7 \mathrm{~b}$ and c). I. iridescens and $H$. japonica underwent an obviously decreasing in impact groups after oil spill experiment. $H$. japonica recovered in low impact groups 35 days after the oil spill impact, yet I. iridescens did not recovered to the previous level in all impact groups (Fig. 7d and e).

\subsection{The changes of community structure}

The macrobenthic abundance data before and after the simulated oil spill was processed with SIMPER analysis by taking different treatments as a whole part. The species composition within the same experimental period maintained high level of similarity. The group similarity before

Table 2

Sediment grain size analysis results.

\begin{tabular}{|c|c|c|c|c|c|c|c|c|}
\hline \multirow[t]{2}{*}{$\%$} & \multicolumn{2}{|c|}{ control } & \multicolumn{2}{|c|}{$500 \mathrm{ml}$} & \multicolumn{2}{|c|}{$2000 \mathrm{ml}$} & \multicolumn{2}{|c|}{$4000 \mathrm{ml}$} \\
\hline & Day $_{-63}$ & Day $_{63}$ & Day $_{-63}$ & Day $_{63}$ & Day $_{-63}$ & $\mathrm{Day}_{63}$ & Day $_{-63}$ & Day $_{63}$ \\
\hline$<4.00 \mu \mathrm{m}$ & 0 & 0 & 0 & 0 & 0 & 0 & 0 & 0 \\
\hline $4.00-24.00 \mu \mathrm{m}$ & 0 & 1.53 & 0 & 1.01 & 0 & 1.26 & 0 & 1.42 \\
\hline $24.00-63.00 \mu \mathrm{m}$ & 5.97 & 7.87 & 8.51 & 7.07 & 9.11 & 5.71 & 7.39 & 5.08 \\
\hline$>63.00 \mu \mathrm{m}$ & 94.03 & 90.60 & 91.49 & 91.93 & 90.89 & 93.03 & 92.61 & 93.51 \\
\hline
\end{tabular}



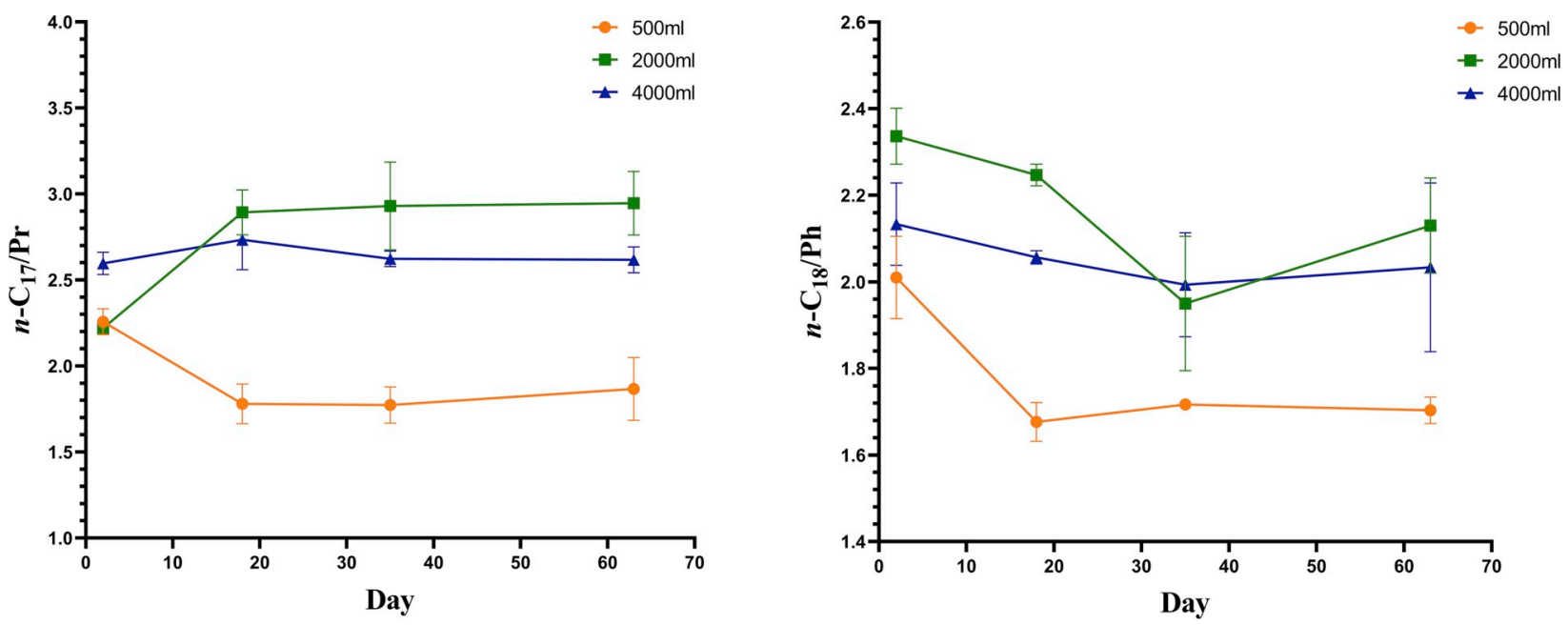

Fig. 3. Degradation of aliphatic hydrocarbons (left $n$-C17/Pr, right $n$-C18/Ph) for 2, 18, 35 and 63 days after the simulated oil spill.

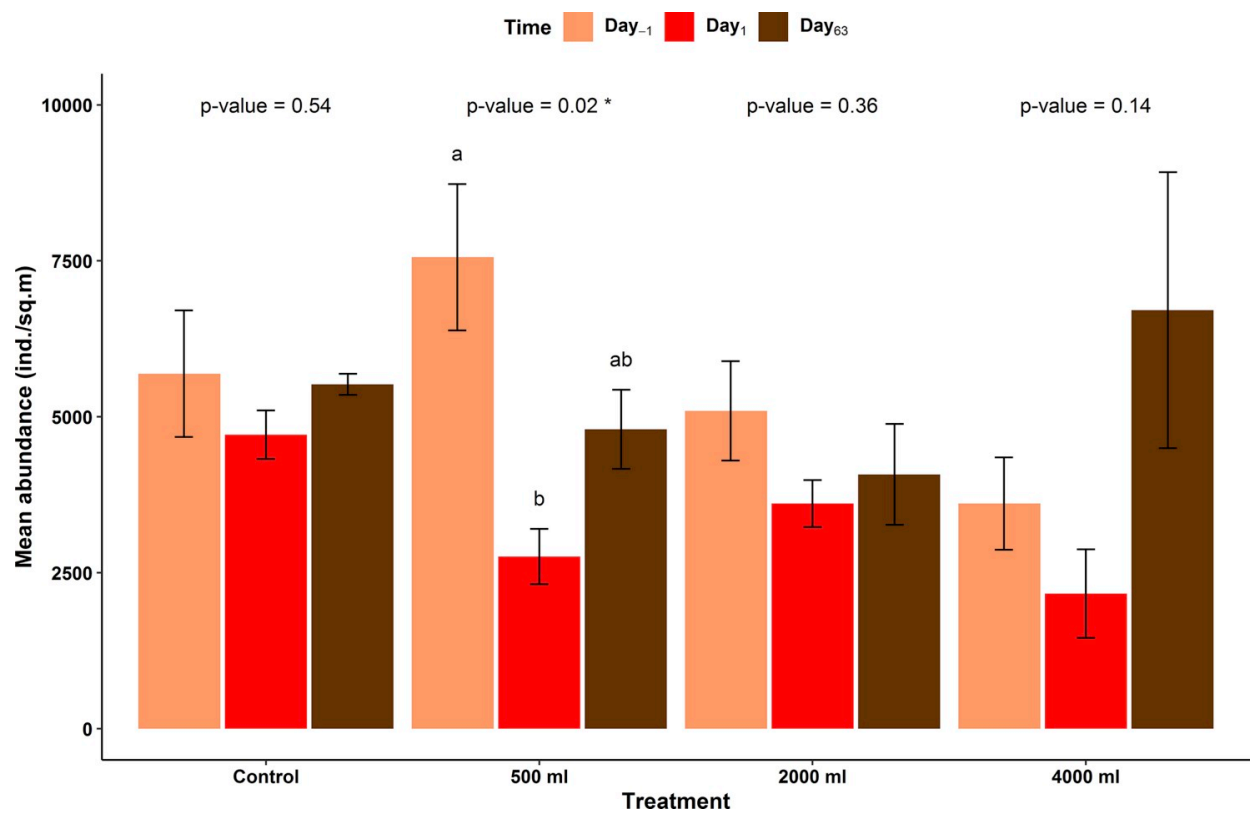

Fig. 4. Mean values of total macrofaunal abundance before (Day ${ }_{-1}$ ) and after impact (Day and $\mathrm{Day}_{63}$ ) in all treatment groups (control and impact). The global pvalues of each treatment group were shown on top ( $p<0.05$ marked as *). Different letters (a, b) indicating statistical significant difference between sampling time within each treatment.

oil spill was $57.81 \%$, among which the characteristic species were I. iridescens, A. intermedia, B. cumingii and $D$. tricincta with contribution rates of $25.17 \%, 20.22 \%, 16.88 \%$ and $14.23 \%$, respectively. The group similarity decreased to $47.28 \%$ after the spill, with $B$. cumingii as the main contributor $(63.08 \%)$. The average dissimilarity coefficient of the two assemblages before and after the oil spill impact was $62.83 \%$, which was contributed by the variation of $A$. intermedia (12.15\%), I. iridescens (11.53\%), D. tricincta (9.84\%), H. japonica (9.13\%) and B. cumingii (8.34\%).

ANOSIM and n-MDS were also performed on the abundance data to study the community divergence before and after the oil spill. The results of these two analyses coordinated well with each other. The macrobenthic assemblages changed significantly before and after the simulated oil spill (global $R=0.351$, significance level $\%=0.1 \%<0.05$, ANOSIM analysis), indicating the oil spill remarkably changed the community structure. Macrobenthic assemblages in all degrees of impact groups displayed significant discrepancy compared with that in control group $(\mathrm{P}<0.05)$. Whereas, significant assemblage discrepancy was detected between $500 \mathrm{ml}$ and $4000 \mathrm{ml}$ impact groups. The results of $\mathrm{n}$-MDS analysis also displayed a decreasing trend of effects from $4000 \mathrm{ml}$ to $500 \mathrm{ml}$. In the 2D plot of n-MDS, the assemblage structure in $4000 \mathrm{ml}$ impact groups differed to a larger extent than that in $500 \mathrm{ml}$ impact group. Moreover, remarkable discrepancy was detected before and after the spill in all impact groups (Fig. 8).

The macrobenthic assemblages before the oil spill displayed significant difference compared to that after the oil impact. Moreover, both abundance and species number showed significant divergence in different treatment groups, which indicates the simulated oil spill impacted the macrobenthic assemblage to different extent along with the oil concentrations. However, both abundance and species number varied insignificantly across different treatments on all sampling days within the same period, which is expressed as $\mathrm{Tr}^{*} \mathrm{Te}(\mathrm{Pe})$ in Table 3, indicating an appropriate and analogous sampling operation before in the experiment temporal scale. Further PERMANOVA analysis also indicated that the macrobenthic assemblages experienced significant variation under different degrees of impact before and after the 


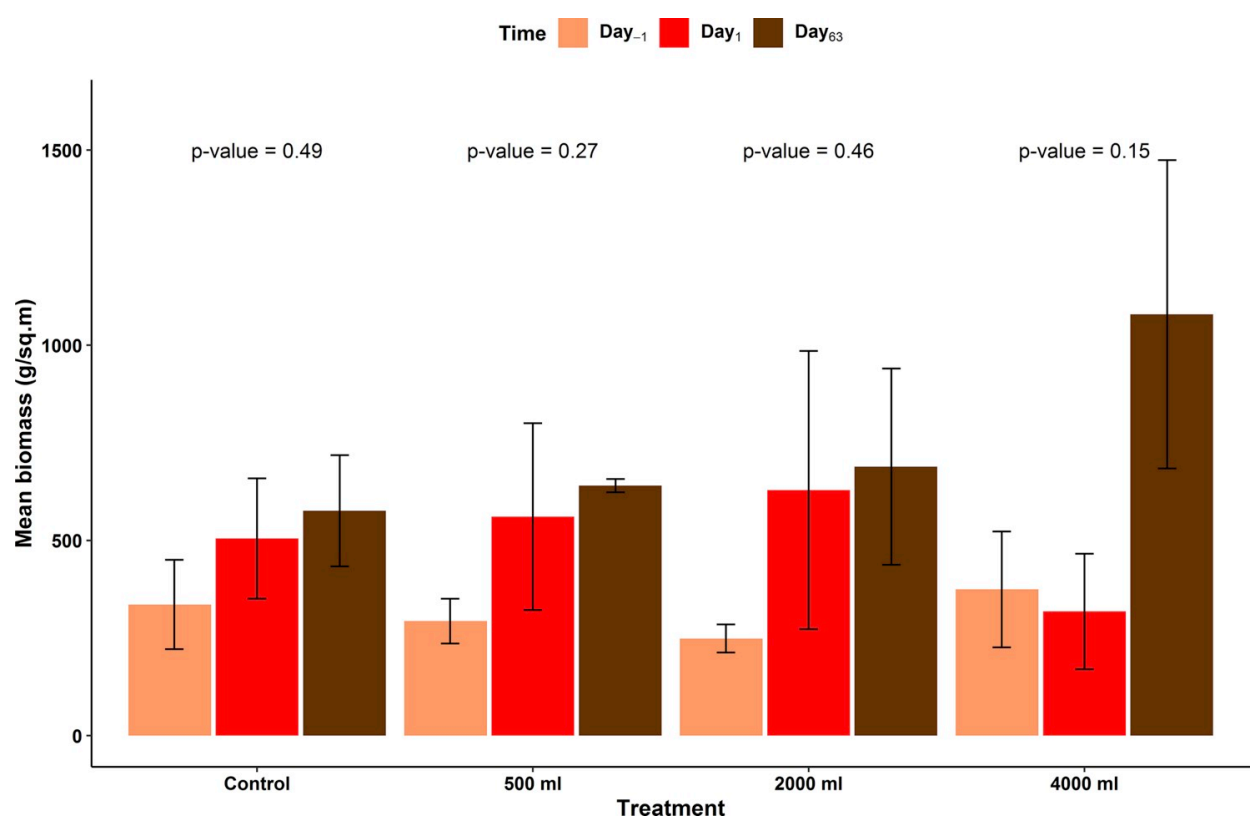

Fig. 5. Mean values of total macrofaunal biomass before (Day-1 ${ }_{-1}$ and after impact (Day ${ }_{1}$ and Day $_{63}$ ) in all treatment groups (control and impact). The global p-values of each treatment group were shown on top.

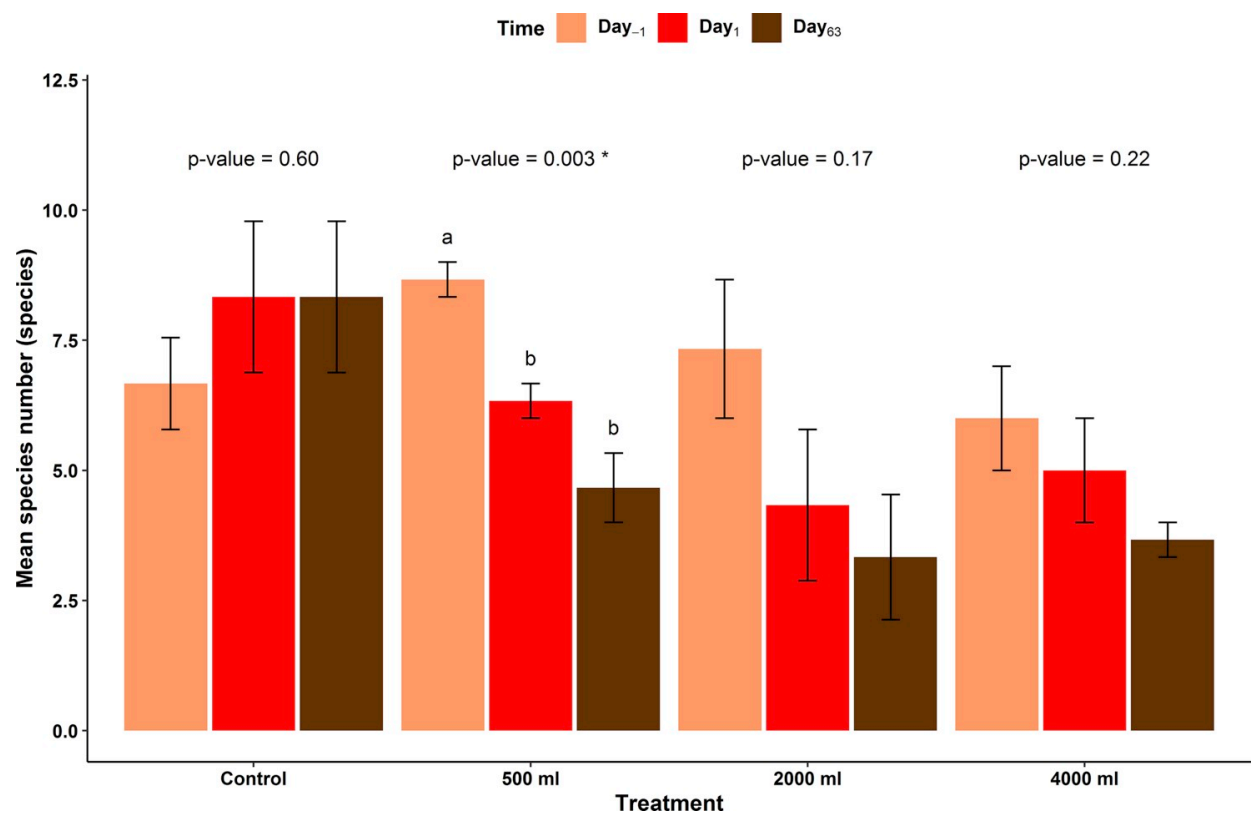

Fig. 6. Mean values of total species number before (Day ${ }_{-1}$ ) and after impact (Day ${ }_{1}$ and $D^{2} y_{63}$ ) in all treatment groups (control and impact). The global p-values of each treatment group were shown on top $(\mathrm{p}<0.05$ marked as *). Different letters $(\mathrm{a}, \mathrm{b})$ indicating statistical significant difference between sampling time within each treatment.

simulated oil spill (Table 4).

\subsection{Community recovery process}

The influence degree of simulated oil spill on macrobenthic fauna varied along with the concentrations of oil. The high concentration spill imposed more severe impact on community than that of low concentration groups. In this experiment, the community structure of $4000 \mathrm{ml}$ oil spill group was more profoundly influenced than that of $500 \mathrm{ml}$ and $2000 \mathrm{ml}$. The number of species decreased sharply on the first day after the simulated experiment and recovered to the pre-spill level over time in $500 \mathrm{ml}$ treatment groups, but not in the $2000 \mathrm{ml}$ and $4000 \mathrm{ml}$ treatment groups (Fig. 9). This confirms our previous anticipation that disturbances at high oil concentrations are more severe than those at low oil concentrations, and that community structures take longer to recover from severe oil spills to pre-spill levels.

\section{Discussion}

Countries all over the world with coastal lines are showing increasing interests in protecting the coastal ecosystems and developing sustainable ways to exploit coastal resources (Barbier et al., 2008; Turner, 2000). As important parts of the coastal zones, intertidal flats are not only essential habitats for macrobenthos (Helmuth et al., 2006; Sprung, 

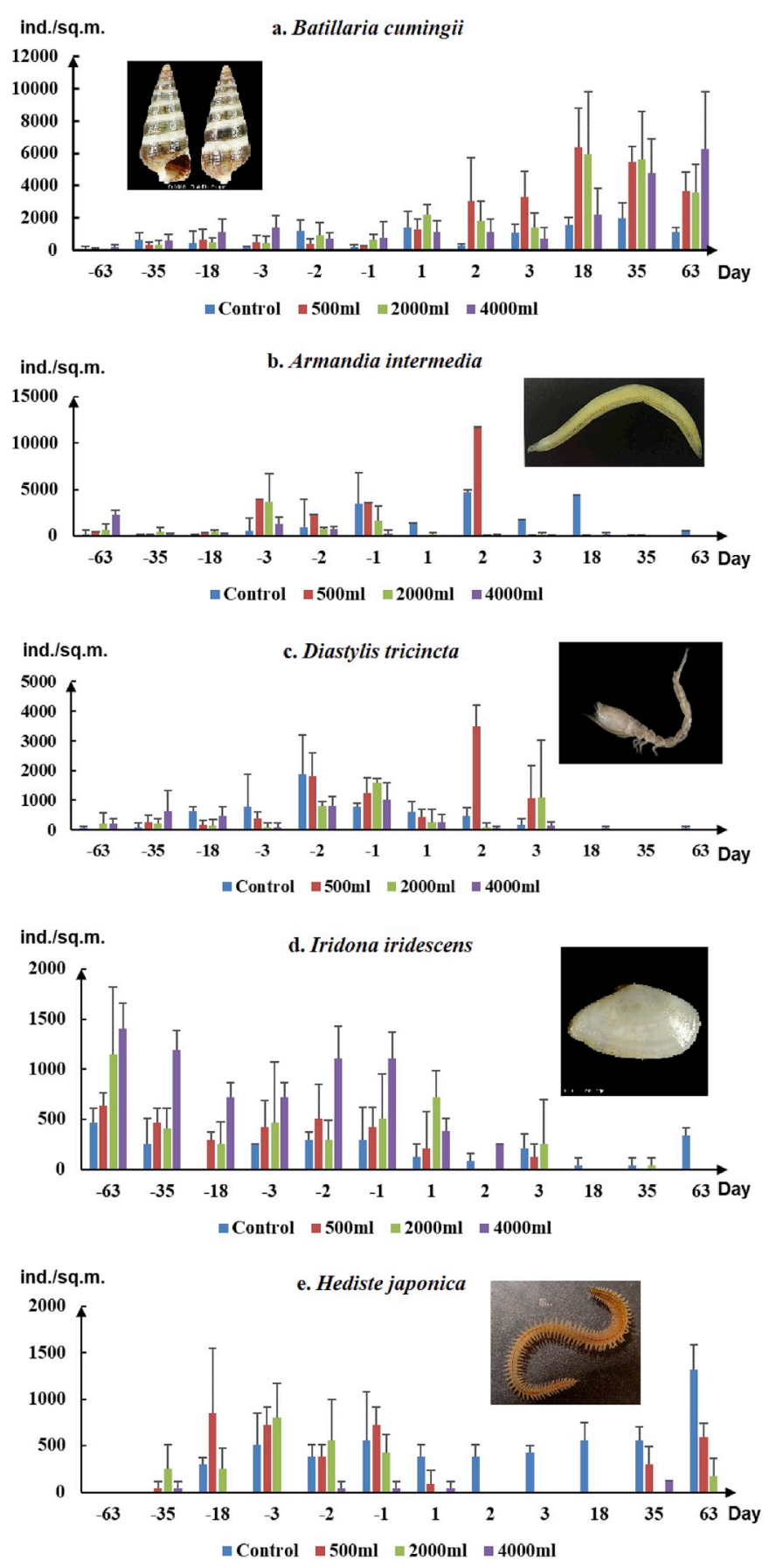

Fig. 7. Temporal variations of the average total abundance in control and impact groups of the dominant species before and after the oil spill experiment. a, Batillaria cumingii; b, Armandia intermedia; c, Diastylis tricincta; d, Iridona iridescens; e, Hediste japonica.

1994), but also the sources for substantial economic benefits (Barbier et al., 2011; Rönnbäck, 1999; Turner, 2000). The intertidal flats are currently experiencing intense pressures from anthropogenic activities such as $i$ ) industrial pollutants (Bárcena et al., 2017; Ferraro et al., 1991), ii) aquaculture chemicals (Gan et al., 2019; Lavoie et al., 2016) and iii) frequent ship waves (Silinski et al., 2015); as well as natural climate change processes including $i$ ) global warming (Kordas et al., 2015; Vafeiadou et al., 2018) and ii) sea level rise (Craft et al., 2009; van der Wegen et al., 2017). Among all these environmental pressures, oil spills are frequently detected worldwide and causing major harms to the intertidal flat ecosystems (Boucher, 1980; Gundlach and Hayes, 1978).
After the 1975 Florida Keys spill, the macrofauna were not found in the polluted areas and the recovery time was more than a half year (Chan, 2013). For the 1978 Amoco Cadiz oil spill, most of the macrofauna disappeared after the spill and took 2-3 years to recover (Conan et al., 2006). For the 2007 Hebei Spirit oil spill happened near South Korea, macrobenthic communities changed in species composition and density while increased in opportunistic species $4-18$ months after the spill. The community structure had a relatively stable faunal composition yet not fully recovered 3 years after this accident (Seo et al., 2014). In the 2002 $\mathrm{T} / \mathrm{V}$ Prestige oil spill happened in Spain, the macrofauna and meiofauna decreased in species richness and density, which were not recovered after 5 years (Junoy et al., 2013). In 1991 Gulf War oil spill and 1996 $\mathrm{T} / \mathrm{V}$ Sea Empress oil spill, it took more than 10 years for all the intertidal invertebrates recovered to the previous level (Banks et al., 2008; Joydas et al., 2017). In countries with frequent aquaculture activities, such as China, diesel oil driven ships are widely used to carry out daily voyages for marine fishing and culturing. This greatly increases the risks of diesel oil spills along the voyage routes from mild to moderate extent caused by the ballast water discharge and mechanical engine failures. Therefore, it is necessary to increase the benthic index content to clarify the biological effects caused by oil spills.

\subsection{The oil pollutants behavior and sediment conditions}

The decomposition process of the petroleum components in the ecosystem is quite slow after an oil spill incident. Some of the petroleum material will naturally deposit into the relatively oxygen-deficient sediment, the other part diffuses into the intertidal zone of the beach with tidal waves and currents (Thibodeaux et al., 2011). The decomposed products contain high level of aliphatic hydrocarbons (AHs), which will pose threats to both aquatic and terrestrial organisms due to its persistent and teratogenic characteristics. Most benthic organisms have limited mobility and have less chance to escape from the oil spill events. This would cause more damage to them. Persistent AHs accumulated in the sediments would induce a decrease in both diversity and density of benthic fauna (Smolders et al., 2004).

In this experiment, the relative contents of AHs experienced a triphase process of increasing-decreasing-increasing in both $500 \mathrm{ml}$ and $2000 \mathrm{ml}$ impact groups. The initial increasing could be attributed to the simulated oil spill treatment, and the subsequent decreasing phase might be caused by natural weathering, drift induced by waves and microbial decomposition. The following increasing trend at the end of the experiment could be caused by the death of the oil-sensitive species, including macrofauna, diatoms and microbes (especially in $2000 \mathrm{ml}$ group). They decomposed after death, increasing the AHs in the sediments. Moreover, the community structure of macrobenthos is closely related to the grain size (Li et al., 2013). The stability of the sediments (check Table 2) in this experiment also indicated that the macrobenthos were less affected by the sediment composition changes but mainly by the diesel oil itself, which were also proved by the ANOVA results.

\subsection{Effects of the simulated oil spill on macrofauna and dominant species}

The impacts of oil spills on macrofauna are complex, with both shortterm and long-term effects. Both the natural variation and the planned effects of the macrobenthic community were considered for the sampling design in this experiment. The M-BACI model and its sampling timescale for 126 days enable us to do continuous observation on the macrobenthic community before and after the stimulated oil spill, specifically the abundance, biomass and dominant species variation. The increasing of $B$. cumingii in both control and impact zones at all sampling time was an assured prove of the natural variability. The recolonization of $H$. japonica was another evidence of the natural succession. However, other dominant species experienced a dramatic drop and then a recover after the oil spill, which was a clear evidence of their biological response to the oil spill. Therefore, observation has shown that the oil spill effects 

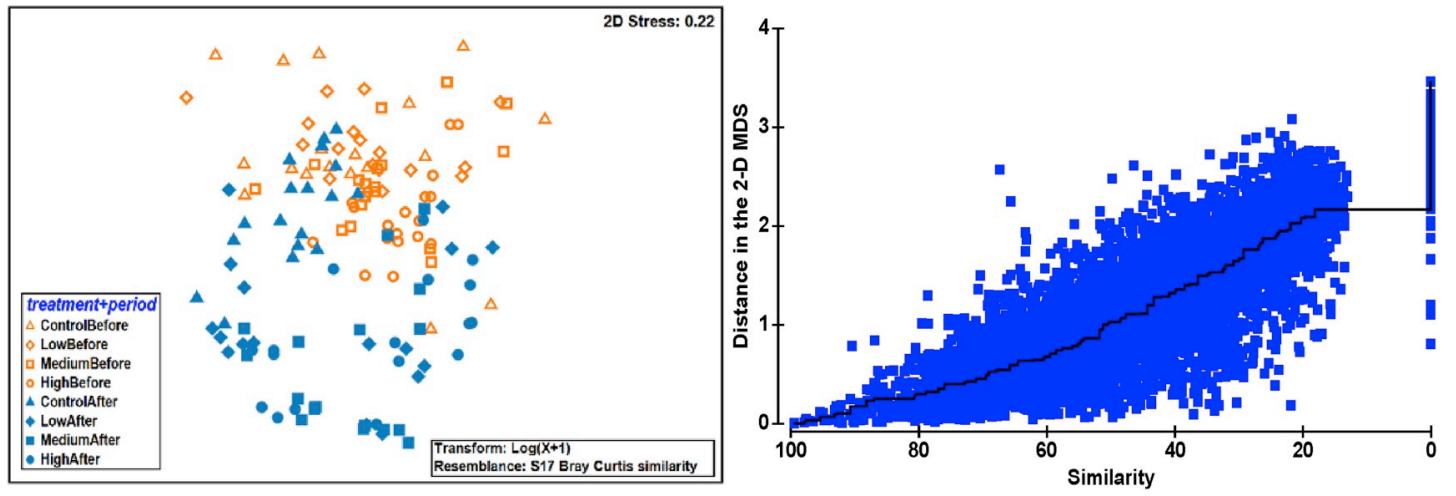

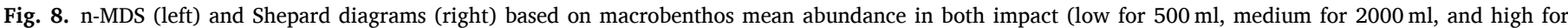

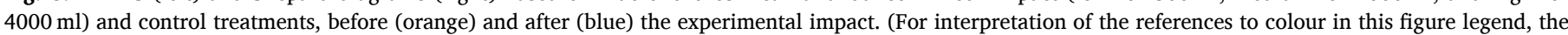
reader is referred to the Web version of this article.)

Table 3

Summary of the ANOVAs for the M-BACI model for abundance and species number.

\begin{tabular}{llllll}
\hline Source of Variation & Df & Sum Sq & F Value & $\operatorname{Pr}(>\mathrm{F})$ & \\
\hline Abundance & & & & & \\
$\operatorname{Tr}$ & 3 & 177.8 & 13.3 & $1.57 \mathrm{E}-07$ & $*$ \\
$\mathrm{Pe}$ & 1 & 449.8 & 98.88 & $<2 \mathrm{e}-16$ & $*$ \\
$\mathrm{Te}$ & 5 & 113.3 & 2.489 & 0.034943 & $*$ \\
$\operatorname{Tr} * \mathrm{Pe}$ & 3 & 197.8 & 14.49 & $3.02 \mathrm{E}-08$ & $*$ \\
$\operatorname{Tr}$ Te (Pe) & 15 & 60.8 & 0.445 & 0.961738 & \\
Species number & & & & & \\
$\operatorname{Tr}$ & 3 & 108.8 & 10.562 & $2.74 \mathrm{E}-06$ & $*$ \\
$\mathrm{Pe}$ & 1 & 81 & 23.594 & $3.22 \mathrm{E}-06$ & $*$ \\
$\mathrm{Te}$ & 5 & 81.7 & 3.779 & 0.00326 & $*$ \\
$\operatorname{Tr} * \mathrm{Pe}$ & 3 & 96.6 & 9.375 & $1.13 \mathrm{E}-05$ & $*$ \\
$\operatorname{Tr} * \mathrm{Te}(\mathrm{Pe})$ & 15 & 43.7 & 0.674 & 0.80554 & \\
\hline
\end{tabular}

Source of variation: treatment $=\mathrm{Tr}$; period $=\mathrm{Pe}$ (before and after the spill); Te $=$ sampling time. Significant interaction $(\mathrm{p}<0.05)$ indicated with *

Table 4

Summary of the PERMANOVA results of abundance for the M-BACI model.

\begin{tabular}{llllll}
\hline Source & df & SS & MS & Pseudo-F & P \\
\hline $\operatorname{Tr}$ & 3 & 22323 & 7441.2 & 9.6982 & $0.001^{*}$ \\
$\operatorname{Pe}$ & 1 & 47153 & 47153 & 61.456 & $0.001^{*}$ \\
$\operatorname{Tr} * \operatorname{Pe}$ & 3 & 18431 & 6143.8 & 8.0073 & $0.001^{*}$ \\
$\operatorname{Tr}$ Te(Pe) & 30 & 34492 & 1149.7 & 1.4985 & $0.001^{*}$ \\
Residual & 94 & 72123 & 767.27 & & \\
Total & 141 & $2.19 \mathrm{E}+05$ & & & \\
\hline
\end{tabular}

Source of variation: treatment $=\mathrm{Tr}$; period $=\mathrm{Pe}$ (before and after the spill); $\mathrm{Te}$ $=$ sampling time. Significant interaction $(\mathrm{p}<0.05)$ indicated with *.

on macrofauna was not covered by the natural successions. This proves that the treatment is valid, and the results are convincible.

Two types of experimental perturbation defined as "pulse" and "press" are related to the responses of macrobenthic communities to simulated disturbance (Glasby and Underwood, 1996). The "pulse" perturbation is a short-term process and can cause sudden changes in assemblage structures. Once the perturbation stopped, the assemblage will recover within a certain period. Whereas, the "press" perturbation is a consistent course with permanent changes on the assemblage diversity and species abundance. The simulated oil spill in this study could be categorized as the pulse perturbation. After the perturbation, the species number and abundance recovered to different degree in response to different oil concentrations (Fig. 9).

Dominant species showed diverse responses to different degrees of oil spill. The $B$. cumingii was largely found in all the impact groups, indicating that they were resilient to the oil impact. This also explained the increasing of the total biomass shown in Fig. 5. The population structure of $B$. cumingii generally shows seasonal patterns in sand-mud sediment. According to Adachi and Wada (1999), the eggs of $B$. cumingii would occur abundantly from spring to summer, then approached peaks in August. Moreover, the newly recruited juveniles (shell length $<1 \mathrm{~mm}$ ) appeared in the first year from July to august, and in the second year they grew to $3-6 \mathrm{~mm}$ by June, then larger size of $5-10 \mathrm{~mm}$ by July. In the third year, these recruits would grow into $15-25 \mathrm{~mm}$. Therefore, the abundance of $B$. cumingii would reach peak in summer, which is consistent with our observations at control areas during July and August (Fig. 7a). In our study, the abundance of B. cumingii increased immediately one day after the oil spill $(500 \mathrm{ml})$, indicating that not only this species was tolerant to the oil contamination but also the oil spill provided favorable habitats for this species. Therefore, its high density observed in the following sampling dates was mainly attributed to its natural proliferation and the favorable habitats caused by lower concentrations of diesel oil spill $(500 \mathrm{ml}$ at the beginning or $2000 \mathrm{ml}$ and $4000 \mathrm{ml}$ for longer degradation time). Due to tolerance to the oil spill, $B$. cumingii should be categorized as "tolerant species".

However, for $A$. intermedia and D. tricincta, their response to the oil spill are opposite to that of $B$. cumingii. The abundance of these 2 species increases sharply on the second day after the oil spill, and then declined or even disappeared on the following sampling dates. The proliferation of $A$. intermedia and $D$. tricincta could be considered as a result of the intermediate disturbance (largely captured in low but not in higher concentration areas). This also led to the increase in total abundance shown in Fig. 4. The $A$. intermedia and $D$. tricincta are bottom swimming species, both of whom can seek for favorable habitats and freely migrate elsewhere when faced with contaminations. The following absence of these 2 species could be attributed to their instinctive escape from the persistent simulated oil spill. Then, $A$. intermedia and $D$. tricinct $a$ could be recognized as "opportunistic species".

I. iridescens and $H$. japonica showed different response patterns from the aforementioned 3 dominant species. They maintained stable abundance in control groups after the oil spill. In the impact groups, the I. iridescens gradually reduced 3 days after the oil spill due to its sensitiveness to the oil contaminants. While they were still captured in the control groups till the last sampling date. The abundance of $H$. japonica in control groups maintained at similar level after the oil spill, yet dramatically decreased in all oil impact groups and slowly recovered until 35 days later. The response process of $H$. japonica well signified the theory of equilibrium state fluctuation. As an equilibrium species of the benthic community, $H$. japonica is sensitive to oil contaminant and initiatively escape the disturbance, resulting in the decreasing of density. With the weakening of pressure (the decomposition of aliphatic hydrocarbons), $H$. japonica gradually recolonized from unpolluted habitats 


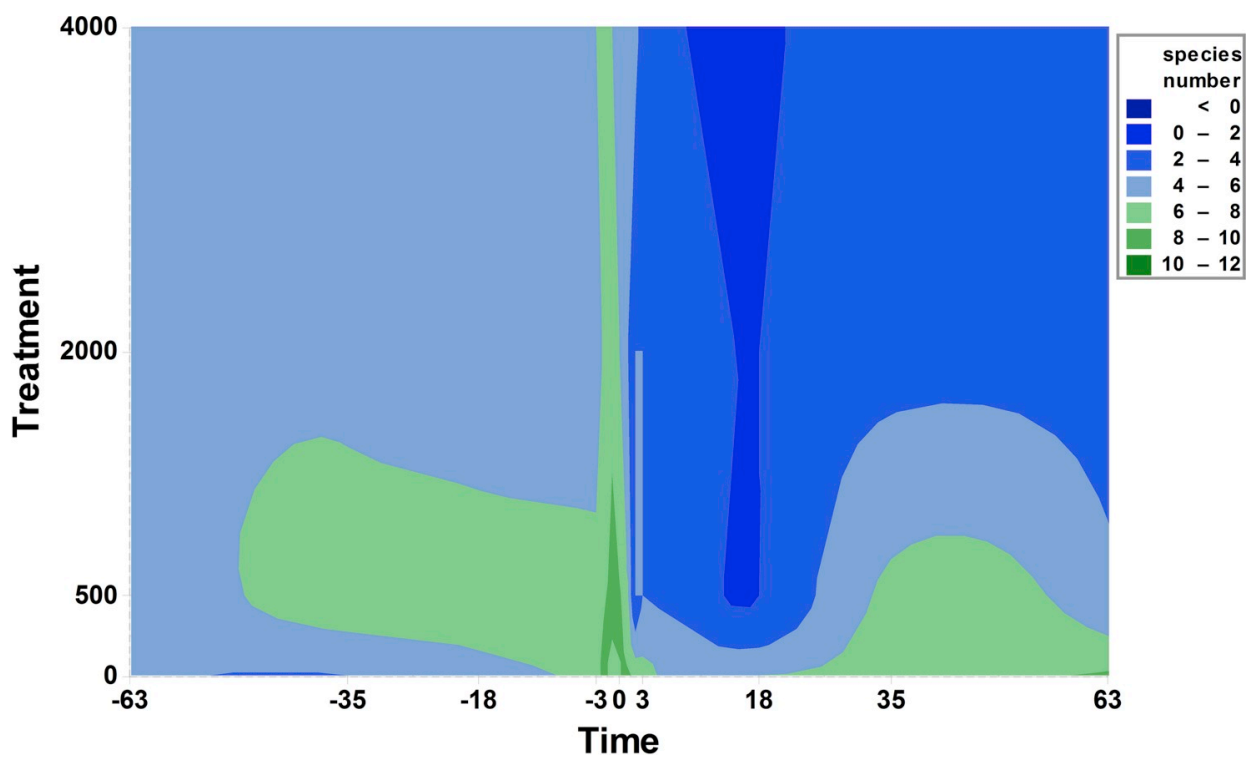

Fig. 9. Changes of species number within experimental duration in isogram.

nearby in low concentration oil spill areas. For this reason, I. iridescens and $H$. japonica could be categorized as "equilibrium species".

\subsection{The recovery process}

In this experiment, the community succession process can be explained by the theory of the intermediate disturbance hypothesis (Connell, 1979; Dial and Roughgarden, 1998; Roxburgh et al., 2004). This theory claims that the diversity and density of any ecosystem remains the highest when the disturbance is at intermediate level. It depicts the temporal process of community variation under the negative impacts of environmental disturbance. According to the equilibrium state summarized by Deangelis and Waterhouse (1987), species will deviate from the stable condition and cause fluctuations in fauna populations under perturbation. The community structure tends to maintain an equilibrium state, though physical and biological events can cause different degrees of loss in density, species number or even removal of the entire community. If the disturbance is at low magnitude, the competitive exclusion will reduce the diversity. If the disturbance is at high level, all the species will suffer and few of them can survive. For this reason, an intermediate rate of disturbance is appropriate for maintaining the assemblage in highest diversity (Osman, 2015).

The $500 \mathrm{ml}$ groups can be considered as intermediate disturbance groups, since the total species number recovered quickly in 18 days after the oil spill (Fig. 9). However, the species number did not recover to the pre-spill level in higher concentration areas $(2000 \mathrm{ml}$ and $4000 \mathrm{ml}$ groups). This phenomenon was also testified by the n-MDS results, for the similarity distance at low oil spill groups before and after the oil spill was closer than that at high oil spill groups. The community structure experienced a more acute variation in $4000 \mathrm{ml}$ group than those in $500 \mathrm{ml}$ and $2000 \mathrm{ml}$ groups, which was also proved by the drastic decrease of species number in the first day after the oil impact.

Some of the dominant species vanished after the oil spill, while others increasing greatly with the stimuli of oil contaminants. The variation of dominant species lead to significant changes in community structure, which was also expressed in results of SIMPER and ANOSIM analysis. The experimental phenomena were coincident with our anticipation: $i$ ) the perturbation in high concentration oil spill group was more severe than that of low concentration group; $i$ ) the faunal recovery under low concentration oil spill impact was faster than that in high concentration oil spill group, but the species composition changed irreversibly.
Intertidal macrobenthos can initiatively adapt and change the surrounding environment in the long-term evolution, including make a regularly selective response to emergent disturbances. The recovery process of macrobenthos after small-scale disturbance is closely related to the following aspects: $i$ ) the proportion of juveniles or adults moving from adjacent areas (Negrello Filho et al., 2006); ii) growth and development rate of larvae (Carman et al., 2000); iii) the tolerance of the re-colonized species to toxic pollutants (Schratzberger et al., 2003). In our study, the recovery of $A$. intermedia and $D$. tricincta could be attributed to the active migration of adults from the surrounding sediments since their density began to increase on the second day after the impact and few juveniles were recorded. The gradual recolonization of $B$. cumingii and $H$. japonica could be attributed to the mixed effects of juvenile growth, larval recruitment and adult migration, since the recovery timescale was quite long with seasonal variations and they were also constantly captured at control groups. This recolonization pattern of intertidal macrobenthic species is probably associated with the evolutionary history of adaptation to natural stressors such as desiccation, high temperatures during tidal exposure, and a correspondingly reduction in feeding and respiration times (Bolam et al., 2004).

There are still more expectations to be fulfilled in the future research, though we have considered both natural and stress succession process in response to the simulated oil spill. The 126-day experimental temporal scale was set according to the environmental conditions and the previous references (Egres et al., 2012), which was not long enough to capture a complete recovery. More concentration gradients and prolonged experimental period should also be set to fully study the effects of different degrees of oil spill on macrofauna structures. The dominant species showed different response patterns to oil spills. Some were sensitive to oil spill disturbance, while others were tolerant. Molecular mechanisms, such as related enzyme activity and gene expression, should be the focus of further research. Although plenty of related studies have been carried out in labs (Pereira et al., 2018; Simonato et al., 2008; Strømgren and Nielsen, 1991), more studies still need to be carried out in situ due to the complex effects caused by multiple factors in the real intertidal ecotypes.

\section{Conclusions}

The macrobenthic communities were significantly influenced by the oil contaminants at the spatial and temporal scales in this experiment. The community abundance and species number gradually recovered at 
low concentration oil polluted areas within 2 months, but not recolonized at high concentration areas.

The macrobenthos responded diversely to various degrees of oil spill impacts at intertidal zone in Laizhou Bay. The higher the oil spill concentration, the more significant the number of species decreased. Some of the species were resilient to the oil spill impact, yet some were sensitive to the planned oil spillage. $B$. cumingii showed similar variation patterns in both control and oil simulation groups and was recognized as "tolerant species". A. intermedia and D. tricincta were recognized as "opportunistic species", which were tolerant to low concentration diesel oil and increase sharply after the simulated spill. I. iridescens and $H$. japonica were fragile to the oil stimulation and categorized as "equilibrium species".

This study assessed the impact of diesel oil spill on intertidal ecosystem with manipulative in-situ experiment. Our findings expanded the database of the ecological risk assessment system for different concentrations of oil spills, in which the ecological responses of macrobenthos were rarely recorded.

\section{Acknowledgments}

This work is supported by International cooperation, CAS, ChineseForeign cooperation in key projects (The detection of oil spill and its ecological impact study. No. 133337KYSB20160002), the Strategic Priority Research Program of the Chinese Academy of Sciences (Grant No. XDA23050304 \& XDA23050202), the self-deployment project of Yantai Institute of Coastal Zone Research, Chinese Academy of Sciences (Grant No. YICY755021012), Shandong Key R\&D Program (Public Welfare Project) (Grant No. 2019GSF109081). And it was co-supported by the Joint research project between China and Russian of CAS, the National Science Foundation of China (No. 41576032). We thank the local managers from Blue Ocean Science and Technology Co., Ltd for their interest and support in implementing the experiments. We are grateful to the two anonymous reviewers and editor for helpful comments and suggestions that improved the manuscript.

\section{Appendix A. Supplementary data}

Supplementary data to this article can be found online at https://doi. org/10.1016/j.marenvres.2019.104823.

\section{References}

Adachi, N., Wada, K., 1999. Distribution in relation to life history in the direct-developing gastropod Batillaria cumingi (Batillariidae) on two shores of contrasting substrata. J. Molluscan Stud. 65, 275-288. https://doi.org/10.1093/ mollus/65.3.275.

Ahn, I.Y., Choi, J.W., 1998. Macrobenthic communities impacted by anthropogenic activities in an intertidal sand flat on the west coast (Yellow Sea) of Korea. Mar. Pollut. Bull. https://doi.org/10.1016/S0025-326X(98)00061-7.

Aller, R.C., 1982. The effects of macrobenthos on chemical properties of marine sediment and overlying water.

Amaro, T., Bertocci, I., Queiros, A.M., Rastelli, E., Borgersen, G., Brkljacic, M., Nunes, J., Sorensen, K., Danovaro, R., Widdicombe, S., 2018. Effects of sub-seabed CO 2 leakage: short- and medium-term responses of benthic macrofaunal assemblages. Mar. Pollut. Bull. https://doi.org/10.1016/j.marpolbul.2018.01.068.

Anderson, M.J., Marti J, A., 2008. Animal-sediment relationships re-visited: characterising species' distributions along an environmental gradient using canonical analysis and quantile regression splines. J. Exp. Mar. Biol. Ecol. https:// doi.org/10.1016/j.jembe.2008.07.006.

Banks, A.N., Sanderson, W.G., Hughes, B., Cranswick, P.A., Smith, L.E., Whitehead, S., Musgrove, A.J., Haycock, B., Fairney, N.P., 2008. The Sea Empress oil spill (Wales, UK): effects on common scoter Melanitta nigra in carmarthen Bay and status ten years later. Mar. Pollut. Bull. https://doi.org/10.1016/j.marpolbul.2008.01.032.

Barbier, E.B., Hacker, S.D., Kennedy, C., Koch, E.W., Stier, A.C., Silliman, B.R., 2011. The value of estuarine and coastal ecosystem services. Ecol. Monogr. https://doi.org/ 10.1890/10-1510.1.

Barbier, E.B., Koch, E.W., Silliman, B.R., Hacker, S.D., Wolanski, E., Primavera, J., Granek, E.F., Polasky, S., Aswani, S., Cramer, L.A., Stoms, D.M., Kennedy, C.J., Bael, D., Kappel, C.V., Perillo, G.M.E., Reed, D.J., 2008. Coastal ecosystem-based management with nonlinear ecological functions and values - supporting material. Science. https://doi.org/10.1126/science.1150349, 80-.
Bárcena, J.F., Gómez, A.G., García, A., Álvarez, C., Juanes, J.A., 2017. Quantifying and mapping the vulnerability of estuaries to point-source pollution using a multi-metric assessment: the Estuarine Vulnerability Index (EVI). Ecol. Indicat. https://doi.org/ 10.1016/j.ecolind.2017.01.015.

Bejarano, A.C., Chandler, G.T., He, L., Coull, B.C., 2006. Individual to population level effects of South Louisiana crude oil water accommodated hydrocarbon fraction (WAF) on a marine meiobenthic copepod. J. Exp. Mar. Biol. Ecol. https://doi.org/ 10.1016/j.jembe.2005.11.006.

Bolam, S.G., Whomersley, P., Schratzberger, M., 2004. Macrofaunal recolonization on intertidal mudflats: effect of sediment organic and sand content. J. Exp. Mar. Biol. Ecol. https://doi.org/10.1016/j.jembe.2004.01.007.

Borja, A., Tunberg, B.G., 2011. Assessing benthic health in stressed subtropical estuaries, eastern Florida, USA using AMBI and M-AMBI. Ecol. Indicat. https://doi.org/ 10.1016/j.ecolind.2010.05.007.

Boucher, G., 1980. Impact of Amoco Cadiz oil spill on intertidal and sublittoral meiofauna. Mar. Pollut. Bull. https://doi.org/10.1016/0025-326X(80)90254-4.

Carman, K.R., Fleeger, J.W., Pomarico, S.M., 2000. Does historical exposure to hydrocarbon contamination alter the response of benthic communities to diesel contamination? Mar. Environ. Res. https://doi.org/10.1016/S0141-1136(99)000720 .

Chan, E.I., 2013. Oil pollution and tropical littoral communities: biological effects of the 1975 Florida Keys oil spill. In: Int. Oil Spill Conf. Proc, vol 1977, pp. 539-542.

Chen, Y., Xu, Z., Wang, Y., Hu Fang, X., Hu, H., Gu, G., 1995. An ecological study on zooplankton in plume front zone of changjiang (Yangtze)river estuarine area I biomass distribution of dominant species. J. Fish. Sci. China 1, 49-58.

Conan, G., Dunnet, G.M., Crisp, D.J., 2006. The long-term effects of the Amoco Cadiz oil spill [and discussion]. Philos. Trans. R. Soc. Biol. Sci. https://doi.org/10.1098/ rstb.1982.0045.

Connell, J.H., 1979. Intermediate-disturbance hypothesis. Science. https://doi.org/ 10.1126/science. 204.4399.1345, 80-.

Craft, C., Clough, J., Ehman, J., Jove, S., Park, R., Pennings, S., Guo, H., Machmuller, M., 2009. Forecasting the effects of accelerated sea-level rise on tidal marsh ecosystem services. Front. Ecol. Environ. https://doi.org/10.1890/070219.

Cusson, M., Bourget, E., 2005. Global patterns of macroinvertebrate production in marine benthic habitats. Mar. Ecol. Prog. Ser. https://doi.org/10.3354/ meps 297001.

Dauvin, J.C., 2000. The muddy fine sand Abra alba-Melinna palmata community of the Bay of Morlaix twenty years after the Amoco Cadiz oil spill. Mar. Pollut. Bull. https://doi.org/10.1016/S0025-326X(99)00242-8.

De Jonge, V.N., 2000. Importance of temporal and spatial scales in applying biological and physical process knowledge in coastal management, an example for the Ems estuary. Cont. Shelf Res. https://doi.org/10.1016/S0278-4343(00)00042-X.

Deangelis, D.L., Waterhouse, J.C., 1987. Equilibrium and nonequilibrium concepts in ecological models. Ecol. Monogr. https://doi.org/10.2307/1942636.

Dial, R., Roughgarden, J., 1998. Theory of marine communities: the intermediate disturbance hypothesis. Ecology. https://doi.org/10.1890/0012-9658(1998)079 [1412:TOMCTI]2.0.CO;2.

Díez, S., Jover, E., Bayona, J.M., Albaigés, J., 2007. Prestige oil spill. III. Fate of a heavy oil in the marine environment. Environ. Sci. Technol. https://doi.org/10.1021/ es0629559.

Egres, A.G., Martins, C.C., Oliveira, V.M., de, Lana, P da, C., 2012. Effects of an experimental in situ diesel oil spill on the benthic community of unvegetated tidal flats in a subtropical estuary (Paranaguá Bay, Brazil). Mar. Pollut. Bull. https://doi. org/10.1016/j.marpolbul.2012.10.007.

Ekeroth, N., Blomqvist, S., Hall, P.O.J., 2016. Nutrient fluxes from reduced Baltic Sea sediment: effects of oxygenation and macrobenthos. Mar. Ecol. Prog. Ser. https:// doi.org/10.3354/meps11592.

Ferraro, S.P., Swartz, R.C., Cole, F.A., Schults, D.W., 1991. Temporal changes in the benthos along a pollution gradient: discriminating the effect of natural phenomena from sewage-industrial wastewater effects. Estuar. Coast Shelf Sci. https://doi.org/ 10.1016/0272-7714(91)90064-I.

Gan, Z., Ma, W., Zhu, M., Meng, T., 2019. Sulfur, iron, and phosphorus geochemistry in an intertidal mudflat impacted by shellfish aquaculture. Environ. Sci. Pollut. Res. https://doi.org/10.1007/s11356-018-04114-w.

Glasby, T.M., Underwood, A.J., 1996. Sampling to differentiate between pulse and press perturbations. Environ. Monit. Assess. https://doi.org/10.1007/BF00414371.

Goldberg, E.D., 1975. The mussel watch - a first step in global marine monitoring. Mar. Pollut. Bull. https://doi.org/10.1016/0025-326X(75)90271-4.

Grassle, J.P., Frederick Grassle, J., 1976. Sibling species in the marine pollution indicator capitella (polychaeta). Science. https://doi.org/10.1126/science.1257794, 80-.

Gundlach, E.R., Hayes, M.O., 1978. Vulnerability of coastal environments to oil spill impacts. Mar. Technol. Soc. J. 12 (4).

Hawkins, S.J., Evans, A.J., Mieszkowska, N., Adams, L.C., Bray, S., Burrows, M.T., Firth, L.B., Genner, M.J., Leung, K.M.Y., Moore, P.J., Pack, K., Schuster, H., Sims, D. W., Whittington, M., Southward, E.C., 2017. Distinguishing globally-driven changes from regional- and local-scale impacts: the case for long-term and broad-scale studies of recovery from pollution. Mar. Pollut. Bull. https://doi.org/10.1016/j. marpolbul.2017.01.068.

Heck, K.L., Able, K.W., Roman, C.T., Fahay, M.P., 2006. Composition, abundance, biomass, and production of macrofauna in a new England estuary: comparisons among Eelgrass meadows and other nursery habitats. Estuaries. https://doi.org/ $10.2307 / 1352320$.

Helmuth, B., Broitman, B.R., Blanchette, C.A., Gilman, S., Halpin, P., Harley, C.D.G., O’Donnell, M.J., Hofmann, G.E., Menge, B., Strickland, D., 2006. Mosaic patterns of thermal stress in the rocky intertidal zone: implications for climate change. Ecol. Monogr. https://doi.org/10.1890/0012-9615(2006)076[0461:MPOTSI]2.0.CO;2. 
Hu, H., Huang, B., Tang, J., Ren, S., Shao, X., 2000. Studies on benthic ecology in coastal waters of bohai and yellow seas. Donghai Mar. Sci. 18, 39-46.

Joydas, T.V., Qurban, M.A., Al-Suwailem, A., Krishnakumar, P.K., Nazeer, Z., Cali, N.A., 2012. Macrobenthic community structure in the northern Saudi waters of the Gulf, 14 years after the 1991 oil spill. Mar. Pollut. Bull. https://doi.org/10.1016/j. marpolbul.2011.11.007.

Joydas, T.V., Qurban, M.A., Borja, A., Krishnakumar, P.K., Al-Suwailem, A., 2017. Macrobenthic community structure in the northwestern arabian Gulf, twelve years after the 1991 oil spill. Front. Mar. Sci. https://doi.org/10.3389/fmars.2017.00248.

Junoy, J., Castellanos, C., Viéitez, J.M., Riera, R., 2013. Seven years of macroinfauna monitoring at Ladeira beach (Corrubedo Bay, NW Spain) after the Prestige oil spill. Oceanologia. https://doi.org/10.5697/oc.55-2.393.

Ko, J.Y., Day, J.W., 2005. A review of ecological impacts of oil and gas development on coastal ecosystems in the Mississippi Delta. Ocean Coast Manag. https://doi.org/ 10.1016/j.ocecoaman.2004.12.004.

Kordas, R.L., Dudgeon, S., Storey, S., Harley, C.D.G., 2015. Intertidal community responses to field-based experimental warming. Oikos. https://doi.org/10.1111/ oik.00806.

Lavoie, M., McKindsey, C., Pearce, C., Archambault, P., 2016. Influence of intertidal Manila clam Venerupis philippinarum aquaculture on biogeochemical fluxes. Aquac. Environ. Interact. https://doi.org/10.3354/aei00167.

Li, Baoquan, Wang, Q., Li, Bingjun, 2013. Assessing the benthic ecological status in the stressed coastal waters of Yantai, Yellow Sea, using AMBI and M-AMBI. Mar. Pollut. Bull. 75, 53-61. https://doi.org/10.1016/j.marpolbul.2013.08.007.

Lumibao, C.Y., Formel, S., Elango, V., Pardue, J.H., Blum, M., Van Bael, S.A., 2018. Persisting responses of salt marsh fungal communities to the Deepwater Horizon oil spill. Sci. Total Environ. https://doi.org/10.1016/j.scitotenv.2018.06.077.

Negrello Filho, O.A., Underwood, A.J., Chapman, M.G., 2006. Recolonization of infauna on a tidal flat: an experimental analysis of modes of dispersal. J. Exp. Mar. Biol. Ecol. https://doi.org/10.1016/j.jembe.2005.07.008.

Osman, R.W., 2015. The intermediate disturbance hypothesis. In: Encyclopedia of Ecology.

Pereira, T.M., Merçon, J., Passos, L.S., Coppo, G.C., Lopes, T.O.M., Cabral, D.S., Scherer, R., Chippari-Gomes, A.R., 2018. Effects of the water-soluble fraction of diesel oil (WSD) on the fertilization and development of a sea urchin (Echinometra lucunter). Ecotoxicol. Environ. Saf. https://doi.org/10.1016/j.ecoenv.2018.06.040.

Peterson, C.H., Rice, S.D., Short, J.W., Esler, D., Bodkin, J.L., Ballachey, B.E., Irons, D.B., 2003. Long-term ecosystem response to the Exxon valdez oil spill. Science. https:// doi.org/10.1126/science.1084282, 80-.

Pezeshki, S.R., Hester, M.W., Lin, Q., Nyman, J.A., 2000. The effects of oil spill and cleanup on dominant US Gulf coast marsh macrophytes: a review. Environ. Pollut. https://doi.org/10.1016/S0269-7491(99)00244-4.

Robertson, B.P., Gardner, J.P.A., Savage, C., 2015. Macrobenthic-mud relations strengthen the foundation for benthic index development: a case study from shallow, temperate New Zealand estuaries. Ecol. Indicat. https://doi.org/10.1016/j. ecolind.2015.05.039.

Rönnbäck, P., 1999. The ecological basis for economic value of seafood production supported by mangrove ecosystems. Ecol. Econ. https://doi.org/10.1016/S09218009(99)00016-6.

Roxburgh, S.H., Shea, K., Wilson, J.B., 2004. The intermediate disturbance hypothesis: patch dynamics and mechanisms of species coexistence. Ecology. https://doi.org/ 10.1890/03-0266.

Roy, J.W., Grapentine, L., Bickerton, G., 2018. Ecological effects from groundwater contaminated by volatile organic compounds on an urban stream's benthic ecosystem. Limnologica. https://doi.org/10.1016/j.limno.2017.01.004.

Schratzberger, M., Daniel, F., Wall, C.M., Kilbride, R., Macnaughton, S.J., Boyd, S.E., Rees, H.L., Lee, K., Swannell, R.P.J., 2003. Response of estuarine meio- and macrofauna to in situ bioremediation of oil-contaminated sediment. Mar. Pollut. Bull. https://doi.org/10.1016/S0025-326X(02)00465-4.

Seo, J.Y., Kim, M., Lim, H.S., Choi, J.W., 2014. The macrofaunal communities in the shallow subtidal areas for the first 3 years after the Hebei Spirit oil spill. Mar. Pollut. Bull. https://doi.org/10.1016/j.marpolbul.2014.03.008.

Silinski, A., Heuner, M., Schoelynck, J., Puijalon, S., Schröder, U., Fuchs, E., Troch, P., Bouma, T.J., Meire, P., Temmerman, S., 2015. Effects of wind waves versus ship waves on tidal marsh plants: a flume study on different life stages of scirpus maritimus. PLoS One. https://doi.org/10.1371/journal.pone.0118687.

Simonato, J.D., Guedes, C.L.B., Martinez, C.B.R., 2008. Biochemical, physiological, and histological changes in the neotropical fish Prochilodus lineatus exposed to diesel oil. Ecotoxicol. Environ. Saf. https://doi.org/10.1016/j.ecoenv.2007.01.012.

Smolders, R., Bervoets, L., De Coen, W., Blust, R., 2004. Cellular energy allocation in zebra mussels exposed along a pollution gradient: linking cellular effects to higher levels of biological organization. Environ. Pollut. https://doi.org/10.1016/j. envpol.2003.09.027.

Sprung, M., 1994. Macrobenthic secondary production in the intertidal zone of the Ria Formosa - a lagoon in southern Portugal. Estuar. Coast Shelf Sci. https://doi.org/ 10.1006/ecss.1994.1037.

Strømgren, T., Nielsen, M.V., 1991. Spawning frequency, growth and mortality of Mytilus edulis larvae, exposed to copper and diesel oil. Aquat. Toxicol. https://doi. org/10.1016/0166-445X(91)90071-G.

Thibodeaux, L.J., Valsaraj, K.T., John, V.T., Papadopoulos, K.D., Pratt, L.R., Pesika, N.S., 2011. Marine oil fate: knowledge gaps, basic research, and development needs; a perspective based on the deepwater horizon spill. Environ. Eng. Sci. https://doi.org/ 10.1089/ees.2010.0276.

Turner, R.K., 2000. Integrating natural and socio-economic science in coastal management. J. Mar. Syst. https://doi.org/10.1016/S0924-7963(00)00033-6.

Underwood, A.J., 2000. Importance of experimental design in detecting and measuring stresses in marine populations. J. Aquatic Ecosyst. Stress Recovery. https://doi.org/ 10.1023/A:1009983229076.

Uno, S., Kokushi, E., Añasco, N.C., Iwai, T., Ito, K., Koyama, J., 2017. Oil spill off the coast of Guimaras Island, Philippines: distributions and changes of polycyclic aromatic hydrocarbons in shellfish. Mar. Pollut. Bull. https://doi.org/10.1016/j. marpolbul.2017.03.062.

Vafeiadou, A.M., Bretaña, B.L.P., Van Colen, C., dos Santos, G.A.P., Moens, T., 2018. Global warming-induced temperature effects to intertidal tropical and temperate meiobenthic communities. Mar. Environ. Res. https://doi.org/10.1016/j. marenvres.2018.10.005.

Van Der Meer, J., Beukema, J.J., Dekker, R., 2001. Long-term variability in secondary production of an intertidal bivalve population is primarily a matter of recruitment variability. J. Anim. Ecol. https://doi.org/10.1046/j.1365-2656.2001.00469.x.

van der Wegen, M., Jaffe, B., Foxgrover, A., Roelvink, D., 2017. Mudflat morphodynamics and the impact of sea level rise in South san Francisco Bay. Estuaries and coasts. .

Wang, C., Du, J., Gao, X., Duan, Y., Sheng, Y., 2011. Chemical characterization of naturally weathered oil residues in the sediment from Yellow River Delta, China. Mar. Pollut. Bull. https://doi.org/10.1016/j.marpolbul.2011.08.021.

Xiong, S., Long, H., Tang, G., Wan, J., Li, H., 2015. The management in response to marine oil spill from ships in China: a systematic review. Mar. Pollut. Bull. https:// doi.org/10.1016/j.marpolbul.2015.05.027.

Yamamoto, T., Nakaoka, M., Komatsu, T., Kawai, H., Ohwada, K., 2003. Impacts by heavy-oil spill from the Russian tanker Nakhodka on intertidal ecosystems: recovery of animal community. Marine Pollution Bulletin.

Zhang, R., Zhang, F., Ding, Y., Gao, J., Chen, J., Zhou, L., 2013. Historical trends in the anthropogenic heavy metal levels in the tidal flat sediments of Lianyungang, China. J. Environ. Sci. (China). https://doi.org/10.1016/S1001-0742(12)60186-7. 